\section{7. 立位膝屈曲撮影の経験}

高知県立西南病院

竹島昌宏・丑本繁樹・森岡 健

岡村隆博・山本浩徳

今回, 当院では Rosenberg の膝屈曲撮影を OA 検査に 試みた，膝の局所部位を調査する目的で立位伸展位，膝 届曲 2 方向を導入し，関節裂隙幅と症状発現肢位の相関 関係を検討し本法の有用性と問題点につき報告する。〔結 果～X線撮影において膝の $\mathrm{OA}$ 変化を詳細に調べる目 的で Rosenberg の膝屈曲 $45^{\circ}$ と立位伸展位, 滕屈曲 $60^{\circ}$ を 追加し, 調查したところ外側顆裂隙幅は届曲位痛で4.3, $5.8,3.9 \mathrm{~mm}$ ，伸展位痛で $4.5,4.9,4.6 \mathrm{~mm}$ であり症状 とX線所見はよく相関していた. 解剖学的に内，外側後 傾角が異なることから，正常膝において入射角の違いで 関節幅が異なることを認めたため，さらに，関節裂隙の 描出能を上げるためには入射角を考慮する必要があると 思われた。

38. 上額洞隍影の定量的測定（第 5 報）

愛媛大学医学部附属病院

○田頭裕之・中田 茂・吉本政弘 川上壽昭

〔目的〕第 4 報に引き続き上額洞陰影の定量的測定の 診断領域での有用性を検討した。

〔方法〕慢性副鼻腔炎疑いにて撮影した144名のX線 を定量解析し，経験年数の異なる 5 名の放射線科医の読 影結果より次のことについて調べた（1)耳鼻科医と放射 線科医の診断の再現性(2)1440個の試料を用いた統計学的 検定による判定基準と定量値の分布図の作成(3)前回との 分布状態の比較

〔結果〕 1. 読影結果は放射線科の再現性が良かった。 2. 判定基準 1 と 2 の平均値の差が 0.08 あ分類できた。 3. 前回に比べ判定基準 1 と 2 の定量值の差が大きく,ま た判定基準 1 の標準偏差が小さくなり好結果を得た。

\section{PTA におけるスケール写し込み装置の検討}

高知医科大学附属病院

○山形憲生・遠山坦彦・山本 登

下司博之・畠山高志・渡辺美穂

PTA 施行時には狭窄部位とバルーンカテーテルの位 置関係把握が重要である. DSA を利用して数 $\mathrm{mm}$ の䛣 差で位置を把握できるスケール写し込み装置を試作し検 討した．装置は発泡スチロールの台座にプラスチック製 円盤を動かすモータを付け，この円盤上にアクリル板に ガイドワイヤーを格子状に配置したスケールを置いたも ので，多重絞り前面に装着する。これを使用することに
より透視像とサブトラクション像のスケールを同一部位 で見えるようにした．試作品はバルーンカテーテルと狭 窄部位との位置関係把握に有用であると好評を得た。

課題として側面方向にも使用可能とする，ブレーキが 定位置で即時停止するようにする，等がある。

\section{0，骨密度測定裝置 QDR-1000 の性能評価}

岡山市立市民病院

○倉田芳文・栗谷正一・岡本祥司

現在，社会的にも問題になってきている骨粗鬆症の診 断に有用とされている骨密度測定装置 QDR-1000 が当 院にも導入されたので，その基本性能（正確度・日差再 現性・日内変動・吸収体厚による影響）について検討し た.

その結果，本装置は正確度に優れ，長期間及び日内で の測定值 $(\mathrm{BMD}, \mathrm{BMC}$, Area) の変動係数が $0.5 \%$ 以下 であり，優れた安定性が確認できた、また，吸収体厚の 測定值に及ほすす影響も，軀幹部における測定については 影響はないと考える。

\section{座長集約}

演題37は, Rosenberg らの立位膝関節屈曲撮影法の使 用経験について述べたものである。

質問 山本（高知）動画ファイルを使用し光ディスク で連続像として解析する試みはメリットがあると思うか.

答 関節裂隙が強調されるのでよいと思う.

質問 島田（高知）諸々の要因で正中がとりにくいと 思うが工夫があるのか.

答 パテラを正面になるように少し振ってやる．実際 にはさほど難しくない.手際良く行うことだ.

演題38は，上頡洞陰影に対し，文部省判定基準と定量 值の関係を求めたものである。

演題39は, PTA 時の位置確認の為のスケール写し込 み装置の試作使用経験を述べたものである。

質問 竹島（高知）実用上でのトラブルはあったか。

答 スケール移動に伴うストッパー部のブレーキ動作 で，ブレ等が生じるのでもう一つ工夫が必要である。

演題40は, Hologic 社製骨密度測定装置 QDR-1000 の 精度試験を述べたものである。

質問 田頭 (愛媛) 毎朝ファントムでフォローしてい るのか. 又, 器材の異常の変動値はどの位とみているか. 答 午後検査開始時にファントムをスキャンし，前日 の BMC, BMD と比べる. 変動率 $1 \%$ 以下を正常とす。

質問 久保（高知）人体で CV はいくらか.

答 今回は調べていない。 